\title{
Unia Europejska - kryzys opowieści, kryzysowa opowieść
}

\section{The European Union: Crisis of Stories and a Crisis Story}

The article focuses on European integration narratives and their emphasis of 'crisis' as the main feature overshadowing and explaining all events and processes. It is argued that the dominant story about the collapsing Union, combined with transformations in the field of communications, creates very difficult conditions for re-creation of a political story outlining a better future. The latter constitutes an indispensible element of the success of the integration process. In fact, re-introduction of such a positive narrative is crucial to solve the crisis and much more important than any institutional innovation. In addition, the article discusses the weaknesses of the 'European camp' that got used to a secure and closed space created by means of transforming political myth into expert knowledge.

Keyword: European Union, EU crisis, EU reforms, political myth, narratives, Emmanuel Macron, researcher's social role.

\section{Wprowadzenie}

Przez ostatnie 10 lat mówienie o Unii Europejskiej niemal zawsze było opowieścią o kryzysie. Określenie to jest odmieniane przez wszystkie przypadki, a okresy, kiedy Unia nie była pogrążona w tym godnym pożałowania stanie, stają się elementem nostalgicznych rozważań o ,starych, dobrych czasach”, które niosły ze sobą oczywiście wyzwania wymagające od decydentów zarządzania, ale podjęcie tych decyzji właściwych i na czas niosło ze sobą sukces. Prowadziło to także do pogłębiania procesu integracji. W epoce kryzysu stanięcie na wysokości zadania oznacza zwykle uniknięcie katastrofy tu i teraz ${ }^{1}$, nie niesie ze sobą pozytywnego komunikatu i tym samym nie może być przykładem skuteczności politycznej przygotowanym do zaprezentowania wyborcom. Oczywiście nie

1 Zob. P. Borkowski, Unia Europejska - groźba implozji, „Rocznik Strategiczny 2011-2012", edycja 16, Warszawa 2012, s. 83-105. 
sposób zaprzeczyć, że wielowymiarowy kryzys² ${ }^{2}$, przede wszystkim wspólnej waluty oraz zadłużenia państw członkowskich, nastąpił i oddziaływał na politykę europejską (european politics), jednak opowiadanie o nim przekroczyło funkcję informacyjną, stając się diagnozą, która wielokrotnie powtarzana i „,redagowania" uzyskała status dominującego komunikatu tudzież hegemonicznego dyskursu. W artykule tym autor starał się rozważyć, na ile kryzysowa narracja stała się samospełniającą się przepowiednią oraz dlaczego zwolennicy pogłębienia jedności Europy mają takie trudności w sformułowaniu nowej, atrakcyjnej opowieści. Autor nie miał natomiast ambicji dostarczenia gotowych zaleceń, lecz uświadomienie złożoności problemu w epoce nowego ,wielkiego uwodzenia” społeczeństwa masowego i jednocześnie zatomizowanego.

\section{„Porzućcie wszelką nadzieję...” - kryzysowa narracja}

Fakt, że Unia jest w kryzysie, stał się aksjomatem, zmienną niezależną i dominującym przekonaniem, które wyznacza zakres postrzegania uczestnikom debaty, niezależnie od tego, czy kryzys jest zjawiskiem realnym. Skoro „wszyscy wiedzą", że Unia jest w kryzysie, nie ma potrzeby naukowej weryfikacji tego założenia, np. przez porównanie wybranych zmiennych z przeszłości, z czasów uważanych powszechnie za okres prosperity projektu integracyjnego. Negatywna konotacja z tym związana ma wiele wymiarów - Unia ,się chwieje”, , ,pogrąża się w chaosie" (ewentualnie bezwładzie), nie wiadomo, czy przetrwa ${ }^{4}$, znajduje się u progu fundamentalnych zmian albo i ,pod ścianą"5, skoro nie będzie w stanie zarządzać tymi zmianami. Sytuacja jest ewidentnie gorsza niż wcześniej-kryzys jest wielowymiarowy i strukturalny ${ }^{6}$, zatem - w domyśle - o wiele

2 Zob. Z. Czachór, Kryzys i zaburzona dynamika Unii Europejskiej, Dom Wydawniczy Elipsa, Warszawa 2013, K.A. Wojtaszczyk, J. Nadolska (red.), Kryzysy w procesie integracji europejskiej $i$ sposoby ich przezwyciężania, Oficyna Wydawnicza ASPRA-JR, Warszawa 2015; D. Dinan, W.E. Paterson, N. Nuggent (red.), The European Union in Crisis, Palgrave Macmillan, New York 2017.

3 M. Michelson, Is The European Union Too Big And Bound To Fail?, www.forbes. $\mathrm{com} / \mathrm{sites} / \mathrm{marcelmichelson} / 2015 / 11 / 27 /$ is-the-european-union-too-big-and-bound-tofail/\#2f1a1e99592d (dostęp: 20.05.2018).

4 D. Weber, Can the EU Survive?, w: D. Dinan, W.E. Paterson, N. Nuggent (red.), The European Union..., s. 336-359.

5 EU survival is AT RISK' Brussels' chief reveals 'existential crisis' in shock admission, www.express.co.uk/news/world/784271/guy-verhofstadt-manfred-weber-eu-brexitnegotiator-european-union (dostęp: 20.05.2018).

6 M. Poboży, Kryzys strukturalny Unii Europejskiej, w: K.A. Wojtaszczyk J. Nadolska (red.), The European Union..., s. 101-118; F. Schimmelfennig, Theorising Crisis in European Integration, w: D. Dinan, W.E. Paterson, N. Nuggent (red.), The European Union..., s. 316-335. 
głębszy i poważniejszy niż wszystkie poprzednie i trudno sobie wyobrazić, jak można mu zaradzić, wykorzystując dobrze rozpoznane instrumenty?

Nieustanne mówienie o kryzysie tworzy określoną, negatywnie nacechowaną narrację, a kryzysowy dyskurs może być wplatany w inne opowieści, które tworzą gęstą sieć, skutecznie wychwytującą niepasujące do niej - pozytywne - komunikaty.

Autor ma określone zdanie, który aspekt kryzysu jest najważniejszy i zasadniczo pierwotny, tj. zawiera się w nim nie tylko diagnoza, ale również geneza i wskazówka co do skutecznego rozwiązania niepożądanej sytuacji. Nie leży on w sferze finansów i gospodarki, gdyż błędem jest uważanie kryzysu finansowego, ,importowanego" z USA po upadku banku Lehman Brothers ${ }^{8}$, za początek i pierwszy akt dramatu. Kryzys procesu integracyjnego trwa co najmniej od 2005 r., tj. od odrzucenia projektu Traktatu ustanawiającego Konstytucję dla Europy w referendach w Holandii i Francji ${ }^{9}$ - czyli państwach założycielskich, a zatem reprezentujących centrum, a nie peryferia procesu integracyjnego. Nie należy redukować go do kryzysu legitymizacji. Jest to kuszące, jednak tworzy niebezpieczeństwo wyciągnięcia niewłaściwych wniosków i zatrzymania się na objawach, a nie przyczynach. Potwierdzenie w badaniach empirycznych deficytu legitymizacji demokratycznej - nawet przy odsunięciu na bok ważnej i fascynującej dyskusji co do konieczności takiej bezpośredniej legitymizacji $^{10}$ - nie oznacza, że „demokratyzacja” bez demos, zwykle proponowana w tym punkcie, przyczyni się do zakończenia kryzysu. Przyczyny braku legitymizacji mogą być zróżnicowane, również w kontekście wielości krajów członkowskich, a hipotezy w tym zakresie trudne do weryfikacji.

7 Autorowi bliski jest pogląd na kryzys projektu integracyjnego wyrażony w P. Vimont, The European Project in Crisis: Myths and Realities, http://carnegieeurope.eu/2017/11/17/ european-project-in-crisis-myths-and-realities-pub-74770 (dostęp: 20.05.2018).

8 Zob. zwłaszcza H. Schmieding, Tough Love: The True Nature of the Eurozone Crisis, „Business Economics” 2012, vol. 47, s. 177-18; J.C. Shambaugh, The Euro's Three Crises, Brookings Papers on Economic Activity, Spring 2012, s. 157-211; M. Götz, Kryzys i przyszłość strefy euro, Difin, Warszawa 2012; T.G. Grosse, Systemowe uwarunkowania kryzysu strefy euro, E-Monografie nr 9, Prace Naukowe Wydziału Prawa, Administracji i Ekonomii Uniwersytetu Wrocławskiego, Wrocław 2010; D. Hodson, EMU and Political Union: What, If Anything, Have We Learned from the Euro's First Decade?, „Journal of European Public Policy” 2009, vol. 16, nr 4, s. 508-526.

9 S. Parzymies, Francuskie i holenderskie „Nie” dla traktatu konstytucyjnego spóźnionym protestem przeciwko rozszerzeniu Unii Europejskiej, „Stosunki Międzynarodowe International Relations" 2005, nr 3/4, s. 75-96.

10 Zob. debata na forum JCMS Menon, S. Hix, A. Folesdahl, Why There is a Democratic Deficit in the EU: A Response to Majone and Moravcsik, ,Journal of Common Market Studies" 2006, vol. 44, nr 3, s. 533-562. 
Zdaniem autora źródeł kryzysu należy upatrywać w warstwie narracyjnej, gdyż załamała się opowieść o wspólnej Europie, obiecującej lepszą przyszłość. Narracja ta była specyficznie konstruowana. Przez dekady stanowiła opowieść elit i rozwijała się wygodnym środowisku konsensusu społecznego. Uczestniczenie w projekcie integracyjnym (ewentualne przyłączenie się do niego) było elementem międzypartyjnego konsensusu wokół zasadniczych celów polityki zagranicznej państwa i jako takie było akceptowane jako element rzeczywistości (analogicznie do członkostwa w ONZ), a nie płaszczyzną sporu np. w kampaniach wyborczych ${ }^{11}$. Poszczególne siły polityczne, różniące się w kwestiach rozwiązań szczegółowych, uznawały jednako członkostwo we Wspólnotach/Unii za należące do pola „racji stanu” ${ }^{12}$. Miało to konsekwencje dla rozwoju narracji o wspólnej Europie - opowieść była snuta i kształtowana przez uczestniczącą w projekcie elitę biurokratyczną, polityczną i akademicką. Komunikaty wypowiadali zaangażowani zwolennicy do innych zaangażowanych zwolenników, ewentualnie przyszłych uczestników, np. słuchaczy studiów europeistycznych przygotowujących się do kariery w strukturach integracyjnych. Na zewnątrz, wraz z rozszerzaniem się Wspólnot, kandydatom głoszono „słowo europejskie”, w którym zawierano „przykazania” i „błogosławieństwa”. Opowieść rozwijała się w obiegu zamkniętym, stawała się samowystarczalna, coraz bardziej rozbudowana i - metaforycznie rzecz ujmując - przeglądała się we własnym odbiciu (i znajdowała w nim akceptację). Wewnętrznie spójna i racjonalna narracja sytuowała się na tym samym poziomie, co opowieść o konieczności bycia w NATO, w organizacji, która jest niezbędna wobec zagrożenia sowieckiego, oraz o ograniczeniach koniecznych, ale słabych wspomnianych już Narodów Zjednoczonych.

Oddziaływanie procesu integracji coraz głębiej i wielowymiarowo na rzeczywistość państw członkowskich oznaczało zawężenie pola manewru władzom

11 Wyjątkiem była kampania parlamentarna 1973 r. w Wielkiej Brytanii, zob. B. Toszek, Proces integracji Wielkiej Brytanii ze Wspólnotami Europejskimi w latach 1961-1975, Wydawnictwo Adam Marszałek, Toruń 2009.

12 Pojęcie racji stanu, szacowne i uświęcone tradycją, zostało mocno zdewaluowane przez dość lekkomyślne używanie, nie tylko przez polityków, ale także innych uczestników debaty. Wobec rozhermetyzowania koncepcji państwa i narodu jako jednolitej wspólnoty, niejako z obowiązku mającej wspólne interesy, jego dalsze używanie musi cechować się daleko posunięta ostrożnością. Nie oznacza to, że myślenie w kategoriach „obowiązkowej” i zamkniętej wspólnoty jest nieobecne, np. w Polsce AD 2018 odgrywa ważną rolę każdy kto nie zgadza się ze sposobem definiowania „racji stanu” przez rządzących, staje się ipso facto uczestnikiem „Nowej Targowicy”. Co do nieprecyzyjnego używania pojęcia racji stanu przez badaczy zob. np. K. Łastawski, Racja stanu Rzeczpospolitej Polskiej, Wyższa Szkoła Pedagogiczna Towarzystwa Wiedzy Powszechnej, Warszawa 2000. 
krajowym (czego przejawem były zwłaszcza ustawy, w których transpozycjonowano reguły unijne zawarte w dyrektywach wspólnotowych). Władze nie mogły dokonywać określonych wyborów, gdyż oznaczałoby to złamanie reguł unijnych, przy jednoczesnym uświadomieniu sobie bycia „dotkniętym” przez Europę. Politycy chętnie tłumaczyli swoją niemoc, tudzież realne zainteresowanie wskaźnikami makroekonomicznymi, wskazując na „Brukselę”, która narzucała reguły i nie pozwalała bez konsekwencji odchodzić od wspólnych uzgodnień, bez względu na to, czy dotyczyły one poziomu deficytu budżetowego, czy niezbędnych warunków sanitarnych obowiązujących na małych targowiskach ${ }^{13}$. Tym samym obywatele zetknęli się z racjonalną i jednokierunkową opowieścią budowaną właściwie nie dla nich. W tym czasie integracja miała już swoje „święte księgi” - traktaty i doktrynę, a także rytuały. Nieprzygotowanego odbiorcę można porównać do laika czytającego literaturę fachową z dowolnej dziedziny nauki. Niezrozumienie, zarówno treści dotyczących działań, jak i motywacji polityków, spowodowało konfuzję i napięcia, które wspólnoty usiłowały rozładować uruchomieniem procesu „demokratyzacji i zbliżania do obywatela"14. Posługując się metaforą, od tego momentu czytanie literatury fachowej stało się zaleceniem, a niekiedy nawet obowiązkiem. W tych warunkach powiedzenie elitom ,nie” było kwestią czasu. Trzeba pamiętać, że z racji zamknięcia i jednokierunkowości opowieści nikt nie był przygotowany na taką odpowiedź, zwłaszcza że była ona ex definitione uznawana za wyraz nieracjonalności. Optymizm związany z zakończeniem zimnej wojny, ewidentny sukces Zachodu w konfrontacji ideologicznej i gospodarczej przedłużył czas generowania napięcia i opóźnił moment rozładowania. Do tego dobra sytuacja gospodarcza przyczyniła się do zamaskowania na jakiś czas problemu. Politycy europejscy zaangażowali się z niekończący się proces reform traktatowych UE, który oznaczał dalsze nagromadzenie literatury fachowej. Gdy zapomniano o sukcesach, pojawiła się niepewność (11 września 2001 r.) i pogorszyła sytuacja gospodarcza, a proces integracji wiązał się z likwidacją czegoś tak namacalnego jak waluta narodowa, opowieść się załamała - krzyknięto, że król jest nagi, a proponowana przyszłość przestała jawić się jako lepsza. Pojawiły

13 Problem węzłów sanitarnych na targowiskach stał się ważnym elementem francuskiej debaty publicznej, w której rząd, nie dokonawszy na czas transpozycji jednej z dyrektyw, pozwolił z satysfakcją na rozwinięcie narracji o Brukseli niszczącej tradycyjną kulturę francuską, która wyraża się m.in. w tradycyjnym handlu.

14 Za symboliczny początek tego procesu można uznać publikację Raportu Adonnino w 1985 r., zob. A People's Europe, Report of the ad hoc Committe, Bulletin of thje European Communities, Supplement 7/85, http://aei.pitt.edu/992/1/andonnino_report peoples_europe.pdf (dostęp: 20.05.2018). 
się siły polityczne, które postulowały powstrzymanie zmian w imię dobrze znanych, sprawdzonych w przeszłości wartości, np. narodu. Podsumowując, u źródeł kryzysu procesu integracji leży załamanie się opowieści o wspólnej Europie, narracji, która była na tyle niezrozumiała i obciążająca oraz związana z szybkimi zmianami, że została odrzucona jako co najmniej podejrzany produkt oderwanych od życia polityków (elit); być może nawet efekt ich świadomego zamiaru „oszukania” społeczeństw. Tym samym do wyjścia z sytuacji kryzysowej nie wystarczy naprawienie (uzupełnienie) mechanizmów $\mathrm{UGW}^{15}$, usprawnienie instytucji czy nawet praktyczne zastosowanie zasady pomocniczości i powrót części kompetencji na poziom narodowy. Potrzebna jest nowa opowieść o wspólnej Europie, która będzie w stanie rywalizować (i wygrać) z licznymi opowieściami o oszustwie i spisku, gloryfikującymi naród, państwo narodowe, wspólnotę etniczną i przeszłość - w dowolnej kombinacji.

\section{Nowa narracja europejska - forma}

Pozytywna narracja zdolna nadać sens procesom i zjawiskom ma ze swej istoty charakter polityczny, w duchu twierdzeń Erica Voegelina o niezbędnej polityzacji wobec oddzielenia dziejów danej zbiorowości od dziejów zbawienia ${ }^{16}$. Powinni ją zatem wygenerować także politycy mający zamiar i odwagę kształtować rzeczywistość i ją zmieniać. Muszą więc wierzyć w sprawczość dobrze skonstruowanej narracji czy wyznawać poglądy dokładnie przeciwne do poglądów wyrażonych niedawno przez premiera Holandii Marca Rutte: ,jeśli masz wizje, powinieneś iść do okulisty" ${ }^{17}$. W tym punkcie wywód mógłby wpaść w utarte tory diagnozowania nieudolności współczesnych polityków europejskich, którzy nie potrafią osiągnąć formatu ich wielkich poprzedników i zasłużyć na miano „męża stanu”. Nie unieważniając tego argumentu, trzeba jednak zadać nieco głębsze pytania. Pierwsze z nich brzmi następująco: czy w strukturze i/lub naturze UE jest coś, co utrudnia tworzenie przekonującej opowieści zdolnej pełnić funkcje legitymizacyjną i mobilizacyjną, przez co potencjalni czempioni tejże opowieści mają na wstępie trudniejsze warunki początkowe względem np. promotorów narracji ksenofobicznej. Jeszcze

15 Zob. M. Dunin-Wąsowicz (red.), Integracja europejska i nowy lad gospodarczy. Raport, Wydawnictwo Naukowe „Scholar”, Warszawa 2012.

16 E. Voegelin, Od Oświecenia do rewolucji, przeł. Ł. Pawłowski, Wydawnictwa Uniwersytetu Warszawskiego, Warszawa 2011.

17 I'm not such a romantic,'Dutch PM says of Juncker's state of the union speech, DutchNews.nl, 14.09.2017, www.dutchnews.nl/news/archives/2017/09/im-not-such-a-romantic-dutch-pm-says-of-junckers-state-of-the-union-speech (dostęp: 20.05.2018). 
ważniejsze jest drugie pytanie - czy jest niezbędne i/lub wskazane proponować jako cel wybraną formę jedności, np. federację europejską. Dodatkowo ta ostatnia sprawa otwiera problem użyteczności i mocy eksplanacyjnej takich XIX-wiecznych pojęć, jak federacja, konfederacja i organizacja międzynarodowa do opisu rzeczywistości XXI w. Oba pytania są istotne przy ocenie stopnia kompetencji i „stanięcia na wysokości zadania” przez decydentów, którzy podejmą się zadania zaproponowania opowieści na miarę wyzwań.

Jeżeli chodzi o naturę UE, to najbardziej oczywistym elementem jest jej złożoność i hybrydowość. Wielopoziomowa struktura, która jest odpowiedzialna za uzgadnianie interesów tak wielu podmiotów i łączy elementy wykonywania relacji władzy z perswazją i socjalizacją uczestników, nie może nie być skomplikowana. Objaśnianie nawet podstaw reguł jej funkcjonowania skutkuje trudnym komunikatem, a odpowiedzi na pytania typu „kto decyduje?” i „kto rządzi?" nie będą jednoznaczne, zatem prawdopodobnie nie zadowolą pytających. Niejednoznaczność jest w swej istocie drugą cechą Unii Europejskiej ważną w kontekście komunikowania się. Wezwania „a mowa wasza ma być tak-tak, nie-nie" nie da się zastosować w procesie komunikowania o zamiarach i aktywności UE. Organizacja nie może być zakwalifikowana bezwzględnie jako dobra/zła, a jej oddziaływanie korzystne/niekorzystne w ogóle i dla całej wspólnoty. Pod tym względem Unia tylko „bywa”, a nie jest, a zależy to od wielu czynników w tym takich, na które państwa członkowskie nie mają wpływu. Sporządzenie bilansu zysków i strat wynikających z uczestnictwa w projekcie integracyjnym to zadanie skomplikowane, część efektów nie jest policzalna, a ewentualny komunikat miałby formę naukowego referatu lub też propagandowego wezwania. Unia łączy oddziaływania i interesy bardzo wielu podmiotów o różnej naturze i pochodzących z różnych poziomów, co w połączeniu z generalnym założeniem o uzgadnianiu i negocjacjach jako metodzie ich agregacji powoduje, że działanie struktury jest długotrwałe, procesy decyzyjne - rozciągnięte w czasie, a cała UE jawi się jako instytucja reagująca irytująco wolno. Nie da się tego zmienić bez porzucenia logiki konsensusu, a ta nie tylko decyduje o właściwej Unii kulturze organizacyjnej, ale także stanowi jeden z fundamentów procesu integracji - warunków niezbędnych do współfunkcjonowania suwerennych państw i częściowo ponadnarodowej, częściowo technokratycznej i częściowo federalnej struktury. Unia - jeśli tylko nie chce stać się wehikułem wykonywania hegemonii - będzie zatem długo debatować i reagować powoli, czego wyrazem będą ,produkty” ogólnikowe i nic niewnoszące, które dla specjalistów niosą komunikat, że debata trwa, ale dla szerszego grona odbiorców jawią się jako bezproduktywne „międolenie”. 
Tymczasem dzisiejsza debata, kształtowana w dużej mierze przez tzw. nowe media, w tym media społecznościowe, wymaga krótkiego, prostego i zdecydowanego komunikatu. Powinien on sytuować się także w ramach jasnego, biało-czarnego przekazu. Krótkie komunikaty, w których operuje się prostym (by nie powiedzieć prostackim) językiem i proponuje konkretne, natychmiast realizowane rozwiązania $w$ ramach dychotomicznego podziału na dobro i zło, to recepta na sukces polityczny, nie ma przy tym znaczenia, czy proponowane rozwiązania są faktycznie możliwe do wprowadzenia. Taki sposób komunikowania stał się znakiem rozpoznawczym np. Donalda Trumpa, który zarówno jako kandydat, jak i prezydent korzystał i korzysta z konta na Twitterze jako głównego środka do porozumiewania się z wyborcami. Dla Unii Europejskiej taki poziom spełnienia wymogów „kultury 180 znaków” jest właściwie nieosiągalny. Może być oczywiście wykorzystywany przez poszczególnych przywódców pełniących funkcje w ramach UE (przykład konta na Instagramie Donalda Tuska lub na Twitterze J.-C. Junckera), ale nie przyczynia się to do skutecznego objaśnienia, jak działa organizacja i dlaczego podjęcie jakiejkolwiek akcji zajmuje jej 6 miesięcy. Polityka krajowa dostosowuje się do wskazanych zmian komunikacyjnych przez spłaszczenie przekazu i kierowanie go do dobrze rozpoznanych grup docelowych. Stopniowy rozpad dyskursu publicznego na nisze, w których zaspokajane są wszystkie potrzeby komunikacyjne, oraz zjawisko, gdy zwolennicy konkretnych partii rozmawiają w zasadzie już tylko sami ze sobą, to najbardziej widoczny efekt.

Proste rozwiązania, jednoznaczne wskazanie winnych i potwierdzenie stania po stronie dobra - to oczekiwania wyborców, coraz chętniej obsługiwane przez przywódców partyjnych, którzy stają się wodzami. Nie ma miejsca na szersze rozważania na ten temat, jednak nawet prosta obserwacja rzeczywistości politycznej Zachodu wskazuje na dobre czasy dla tego typu przywódców, co Victor Orban i Matteo Salvini.

Uprawnione wydaje się zatem twierdzenie, że nie są to czasy sprzyjające tworzeniu opowieści w wspólnej Europie - konieczność „wythumaczenia” jej laikom w warunkach wskazanych zmian komunikacyjnych to zadanie niezwykle trudne. Aby dopełnić obrazu, należy dodać jeszcze dwa - pesymistyczne, ale nieobowiązkowe - elementy. Pierwszy z nich to objaśnienie niechęci do elit w kategoriach resentymentu, które zaproponował Peter Sloterdijk w niewielkim, acz ważnym eseju Pogarda mas ${ }^{18}$; drugi - diagnoza politycznych konsekwencji wykorzenienia i konieczności podołania zadaniu świadomego zaprojektowania

18 P. Sloterdijk, Pogarda mas. Szkic o walkach kulturowych we wspótczesnym spoleczeństwie, przeł. B. Baran, Czytelnik, Warszawa 2012. 
siebie, której dokonał Anthony Giddens ${ }^{19}$. Oba wskazują na podatność członków społeczeństwa ponowoczesnego ${ }^{20}$ na propozycje ideologiczne zdejmujące z ich barków konieczność podejmowania decyzji o znacznej randze moralnej na rzecz wybranych - być może przypadkowo - przywódców. Należy wyraźnie stwierdzić - napisana językiem fachowym opowieść o tym, jak Unia przyczynia się do poszerzenia możliwości i większej swobody realizacji indywidualnej wonności nie spotka się ze zrozumieniem i poparciem. Indywidualna wolność jest bowiem zagrożeniem dla doskonałej wspólnoty „skończonej”21 , która zapewnia bezpieczeństwo i ,swojskość” swoim członkom. Nawet takie pojęcia jak demokracja i wolność są w jej ramach zdefiniowane i reglamentowane ${ }^{22}$. Opowieść o UE musi być zatem ,polityczną baśnią” porównywalną pod względem zasad konstrukcji do innych narracji tego typu. Tymczasem politycy europejscy przez

19 A. Giddens, Nowoczesność i tożsamość, przeł. A. Szulżycka, Wydawnictwo Naukowe PWN, Warszawa 2010; idem, Konsekwencje nowoczesności, przeł. E. Klekot, Kraków 2008, tam zwłaszcza rozdz. 1.

20 Autor nie przywołuje niezwykle ważnego dorobku Zygmunta Baumana, który dostarczył szczególnie istotnego obrazu społeczeństwa ponowoczesnego celowo - jego zdaniem płynność diagnozowana przez Baumana jest cechą, która ustępuje przed imperatywem ładu, jakiegokolwiek ładu, nawet opresyjnego, który jest niezbędny jako kluczowy element pozbycia się indywidualnej odpowiedzialności za podejmowanie decyzji moralnych.

21 Problem otwartości społeczeństwa w duchu rozważań Karla R. Poppera jest istotny w kontekście obecnego kryzysu demokracji (liberalnej). Zwolennicy nieliberalnych jej odmian rozumują właśnie w ramach wspólnoty skończonej - jej cechy zostały określone, system wartości zdefiniowany, warunki przynależności wskazane. Nie można już do niej nic dodać, gdyż byłoby to jak zanieczyszczanie wybranego już koloru. Kontynuując tę nieco ryzykowną metaforę, niechciany dodatek niszczy barwę, niesłychanie trudno go usunąć, potrafi wpłynąć niepostrzeżenie przez nieostrożność. Zbyt wiele obcych odcieni potrafi całkowicie zmienić barwę plamy, która tym samym straci swoją tożsamość i stanie się nieokreślona. Skoro wspólnota jest skończona, to posiada pełnię wiedzy o sobie i rozpoznała prawdę, którą podejmuje się bronić. Takie postrzeganie rzeczywistości jest nie do pogodzenia $\mathrm{z}$ demokracją liberalną, która zakłada, że nikt nie ma pełni wiedzy ani o przeszłości, ani o teraźniejszości, ani o przyszłych konsekwencjach podejmowanych działań. Prawda nie należy do żadnej grupy społecznej czy partii politycznej, lecz negocjują one instrumenty i wysiłki jak najwłaściwszego radzenia sobie z wyzwaniami z wykorzystaniem niepełnej wiedzy o rzeczywistości, zob. szerzej P. Borkowski, Między poszukiwaniem prawdy o spoleczeństwie a jej posiadaniem - demokracja liberalna w odwrocie, „Myśl Polityczna i Ekonomiczna” 2018 (w przygotowaniu).

22 Egzemplifikacją tego stanowiska mogą być słowa posłanki Krystyny Pawłowicz, znanej przeciwniczki Unii Europejskiej, wypowiedziane okolicznościowo: „1 maja 2004 r. Polska stała się oficjalnie członkiem Unii Europejskiej. Z Unią nie łączy Polski żaden wspólny system wartości. Całkowicie odmiennie rozumiane są w Polsce i w UE tak fundamentalne pojęcia i zjawiska jak demokracja, prawo czy rodzina. Dziś bronimy przed UE (gł. przed Niemcami i Francją) resztek naszej narodowej i państwowej suwerenności, stawiamy opór kulturowej agresji unijno-lewackiej. Jesteśmy poddani dyktatowi unijnych, niemających legitymacji wyborczej, lewaków. UE stała się ośrodkiem walki z suwerenną Polską i jej demokratycznie wybranymi władzami”. 
około 25 lat działali w przekonaniu, że ich rolą jest zarządzanie, a nie dostarczanie sensu trwania i rozwijania wspólnot, gdyż te jawiły się jako zbyt złożone i pluralistyczne, aby zaproponować jedną opowieść. Stąd skupienie na mechanizmach zarządzania w duchu regulatory state Giandomenica Majone ${ }^{23}$. O ile założenie, że rynek nie jest właściwym narzędziem tworzenia wspólnoty (Gemeinschaft) jest słuszne, o tyle projekt europejski był zawsze z gruntu polityczny, nawet jeśli zakryty rzeczywistością rynkową. Być może politycy sami uwierzyli, że w ich mocy oddziaływania znajduje się - i powinien się znajdować - tylko rynek. Taka kapitulacja stworzyła przestrzeń dla tych sił politycznych, które nie bały się nadawać sensu wybranym fragmentom rzeczywistości, czy to pod postacią obrazu najazdu na Europę obcych kulturowo emigrantów, czy też redukcji UE do wykonawcy poleceń prawdziwych władców współczesnego świata, czy mieliby to być kapitaliści z klubu Bildenberg, masoni czy weganie i cykliści²4.

\section{Nowa narracja europejska - (nie)beznadziejna treść}

Drugie zagadnienie dotyczy treści wspomnianej opowieści. Czy niezbędne jest określenie końcowej formy organizacyjnej „nowej lepszej wspólnej Europy” i - jako kolejny krok - czy należy używać w tym celu pojęć takich jak federacja, konfederacja czy jeszcze innych określeń dostarczanych przez prawo międzynarodowe i historię dyplomatyczną ${ }^{25}$. Oba zagadnienia są powiązane i mają istotne znaczenie dla oceny skuteczności przygotowywanej pro-europejskiej propozycji.

Pozornie określenie finalité politique procesu integracji jawi się jako uczciwe, pożądane i dające opowieści odpowiedni punkt ciężkości - ,gwiazdę przewodnią", ku której należy zmierzać. Jednak sprawa jest o wiele mniej oczywista. Rozważając, czy pierwotna opowieść „ojców założycieli” zawierała ten element, napotykamy głęboką niejednoznaczność. W deklaracji Schumana oprócz wskazania metody - „krok po kroku” - można go odnaleźć: „Umieszczenie produkcji węgla i stali pod wspólnym zarządzaniem zapewni natychmiastowe powstanie

23 G. Majone, The Rise of the Regulatory State in Europe, „West European Politics” 1994, vol. 17, nr 3; idem, From Regulatory State to a Democratic Default, ,Journal of Common Market Studies" 2014, vol. 52, nr 6, s. 1216 i nast.; por. M. Lodge, Regulation, the Regulatory State and European Politics, „West European Politics” 2008, vol. 31, nr 1-2, s. 280-301.

24 Autor nawiązuje do słynnej wypowiedzi ministra spraw zagranicznych Rzeczpospolitej Polskiej Witolda Waszczykowskiego dla mediów niemieckich. Oryginalny tekst wywiadu dla „Bild” www.bild.de/politik/ausland/polen/hat-die-regierung-einen-vogel-44003034. bild.html (dostęp: 20.05.2018).

25 Użycie najstarszego określenia, poprzedzającego powszechne użycie terminu „stosunki międzynarodowe”, które zostało utrwalone w „kanonicznym” zbiorze dokumentów pod redakcją L. Gelberga, jest całkowicie zamierzone. 
wspólnych fundamentów rozwoju gospodarczego, pierwszego etapu Federacji Europejskiej, i zmieni los regionów, długo skazanych na wytwarzanie wojennego oręża, którego były najdłużej ofiarami. [...] Przez umieszczenie podstawowej produkcji pod wspólnym zarządem i instytucję nowej Wysokiej Władzy, której decyzję zwiążą Francję, Niemcy i kraje, które do niej przystąpią, ta propozycja stanie się pierwszą konkretną podstawą Federacji Europejskiej, niezbędnej dla zachowania pokoju" ${ }^{26}$. Jednak dalszy rozwój procesu integracyjnego w praktyce oznacza zamazywanie tego celu. Nie chodzi tylko o zmianę balansu między tym, co ponadnarodowe, a tym, co międzyrządowe, jaka zaszła między formułowaniem traktatu paryskiego w $1951 \mathrm{r}$. a traktatów rzymskich w latach 1956 i $1957^{27}$, lecz na skupieniu się na funkcjonalnej metodzie. Czy dokonano tego zamazania w wyniku niemożliwego do przezwyciężenia rozziewu opinii między rządami pierwotnych członków Wspólnot, zwłaszcza w konsekwencji przejęcia władzy we Francji przez gen. Charles'a de Gaulle’a i powołania V Republiki, czy też uznano tę kwestią za nieistotną na określonym etapie, może to być wciąż przedmiotem interesujących badań dla historyków integracji. Nie zmienia to faktu, że wspólna Europa jako zasadniczy przedmiot narracji nie została „ubrana” w konkretne ramy organizacyjne. Dowodzi tego język zarówno raportu Tindemansa z 1975 r., jak i Uroczystej Deklaracji o Unii Europejskiej ze Stuttgartu. Pierwszy z tych dokumentów potwierdza drogę stopniowego wzmacniania jedności i całkowicie pomija słowo „federacja”. W konkluzji czytamy: ,The progress achieved as a result will gradually transform the nature and intensity of relations between our States" - brak jest odniesienia co do efektu końcowego tej transformacji ${ }^{28}$. Również dyskusja na temat treści traktatu

26 Deklaracja Schumana - 9 maja 1950 r., https://europa.eu/european-union/about-eu/symbols/europe-day/schuman-declaration_pl (dostęp: 20.05.2018).

27 P. Borkowski, Międzyrządowość w procesie integracji europejskiej, Oficyna Wydawnicza ASPRA-JR, Warszawa 2013, s. 175-200.

28 Widać to jeszcze wyraźniej przy zakreślaniu zasiągu propozycji zmian dokonanych na początku dokumentu. Trudno o tekst bardziej podkreślający niechęć do definiowania finalité politique niż poniższy pasaż: „In order to achieve these tasks European Union is given institutions with the necessary powers to determine a common, coherent and all- inclusive political view, the efficiency needed for action, the legitimacy needed for democratic control. The principle of the equality of all our States continues to be respected within the Union by each State's right to participate in political decision making. Like the Community whose objectives it pursues and whose attainments it protects European Union will be built gradually. So as to restart the construction of Europe straight away and increase its credibility its initial basis is the political commitment of the States to carry out in different fields specific actions selected according to their importance and the chances of success". Pełen tekst raportu http://aei.pitt.edu/942/1/political_tindemans_report.pdf, thumaczenie fragmentów dostępne w: S. Parzymies (wybór i oprac.), Integracja europejska $w$ dokumentach, Warszawa 2009, s. 280 i nast. 
z Maastricht dotycząca sformułowania „coraz bliższy związek - ever closer union" ${ }^{29}$ pokazuje, że opowieść skupiała się na celach ogólnopolitycznych (pokój, dobrobyt, standardy socjalne) oraz metodach (trudno zliczyć odwołania do „metody Monneta”), a nie na zdefiniowaniu finalité politique. Potwierdził to także ostatni z „ojców założycieli wspólnej Europy Jacques Delors, gdy stwierdził, że Unia Europejska jest «niezidentyfikowanym obiektem politycznym»" ${ }^{30}$, choć wiemy, że był i jest zwolennikiem federalizacji Europy.

Tym samym zachowuje aktualność pogląd wyrażony przez klasyka rozważań o integracji europejskiej Stanleya Hoffmanna mniej niż 10 lat po podpisaniu traktatów rzymskich: „Logika integracji jest podobna do blendera, który zgniata najróżniejsze produkty, przezwycięża ich odmienne smaki i zapachy, i zastępuje jednym, przypuszczalnie przepysznym sokiem. [...] Jego nieokreśloność raczej pomaga, niż jest przeszkodą, ponieważ każdy «składnik» może mieć nadzieję, że w efekcie końcowym jego smak przeważy”31.

Konsekwencją uznania, że logika niedopowiedzenia wyznaczyła przestrzeń do twórczego i elastycznego realizowania, rozbudowywania i interpretacji celów traktatowych jest nie tylko przyznanie, że droga integracji nie musiała wyglądać tak, jak wygląda - nie była zdeterminowana w umowie międzynarodowej wyznaczającej początek wspólnoty (wspólnot). Państwa członkowskie i instytucje ponadnarodowe prezentowały różnorodne propozycje interpretacji zapisów traktatów i w toku interakcji uzgadniały, która zostanie uznana za „kanoniczną”. Czasem oczywiście była tylko jedna interpretacja proponowana przez najbardziej zainteresowany podmiot, czasem spór był intensywny i trwały. Jednak kolejne wybory stopniowo zawężały pierwotnie szeroki zakres rozwiązań mieszczących się w nadanych przez traktaty rzymskie - i kolejne - ramach. W tym świetle kryzysy procesu integracji są naturalnym przejawem nawigowania po zwężającym się kanale do wyznaczonego na horyzoncie celu - momentem zbliżania się do granic

29 M.J. Baun, An Imperfect Union: The Maastricht Treaty and the New Politics of European Integration, Westview Press, Boulder 1996.

30 Używał tego określenia wielokrotnie, pierwszy raz publicznie najprawdopodobniej podczas otwarcia konferencji międzyrządowej państw członkowskich Wspólnot w 1985 r., zob.: Speech by Jacques Delors (Luxembourg, 9 September 1985), www.cvce.eu/content/ publication/2001/10/19/423d6913-b4e2-4395-9157-fe70b3ca8521/publishable_en.pdf (dostęp: 20.05.2018); por. G. Ross, J. Jenson, Reconsidering Jacques Delors' Leadership of the European Union, „Journal of European Integration” 2017, vol. 39, nr 2, s. 113-127.

31 S. Hoffman, Obstinate or Obsolate? The Fate of Nation-State and the Case of Western Europe, „Daedalus. Journal of the American Academy of Arts and Sciences” 1966, vol. 95, nr 3, s. 882 . 
i zmiany kursu. Im bardziej zaawansowany jest proces i im węższy kanał, tym kryzysy następują częściej, są mocniej zarysowane i mogą prowadzić do opuszczenia procesu, gdy dane państwo przekonuje się, że jego wizja integracji nie przeważy albo może zostać zmarginalizowana. Tak też można rozumieć postępującą alienację Wielkiej Brytanii, która zakończyła się ostatecznie decyzją o opuszczeniu Unii Europejskiej.

Warto rozważyć, czy kryzys zapoczątkowany w 2005 r. wpisuje się w takie rozumienie procesu integracji. Jeżeli podążymy za sposobem argumentacji Stanisława Parzymiesa, który stwierdził, że negatywny wynik referendów był spóźnionym sprzeciwem wobec rozszerzenia UE na wschód, to dochodzimy do ciekawej konstatacji - niegotowe na kolejne ważne kroki społeczeństwa europejskie, których mimo narracji o zbliżaniu UE do obywatelu w zasadzie nie pytano o zdanie we wspomnianej kwestii rozszerzenia, ale także w jeszcze bardziej dotykalnej kwestii euro, wyrażały swój sprzeciw wtedy, kiedy było to możliwe. Referenda dotyczące Traktatu konstytucyjnego były pierwszą nadarzającą się okazją, podobnie jak wybory parlamentarne, w których partie antyunijne pojawiły się już nie tylko jako elementy folkloru politycznego. Nie było przypadkiem, że holenderska Partia Wolności zaistniała po raz pierwszy w wyborach w 2006 r., a zdobyła rekordowe poparcie wynoszące ponad 15\% w kolejnym głosowaniu powszechnym w 2010 r. Podobnie Prawdziwi Finowie stali się znaczącą siłą w 2007 r., zdobywając 4\% głosów i po raz pierwszy więcej niż jeden mandat, a Duńska Partia Ludowa odniosła sukces w wyborach w 2005 r. Można zatem zaryzykować twierdzenie, że społeczeństwa europejskie wyraziły swój brak gotowości na kolejne „zawężenia kanału" przy nadążającej się okazji, a brytyjskie referendum z 2016 r. było tego skrajną postacią. Oznacza to także, że politycy proeuropejscy okazali się niezdolni albo nieprzygotowani do skutecznego uwiedzenia wyborców ideą europejską. Określenie „uwiedzenie” zostało użyte celowo - bez uznania, że argumentacja racjonalna nie jest wystarczającym ani szczególnie skutecznym narzędziem w kształtowaniu postaw społecznych w pierwszej ćwierci XXI w., nie sposób myśleć o zakończeniu aktualnej sytuacji kryzysowej. Na tym polega zasadniczy powrót istoty polityczności - europejscy przywódcy muszą wyrwać się z przekonania, że istotą jest dyskusja o zarządzaniu w ramach paradygmatu neoliberalnego i zmierzyć się sytuacją, w której stawką wyborów jest redefinicja racji stanu, do której chętnie się odwołują jako elementu ponadpartyjnego konsensusu. Sytuacja polityczna w Polsce, na Węgrzech, być może także we Włoszech po wyborach z kwietnia 2018 r. to namacalny dowód zasadniczego wzrostu stawki, o którą toczy się gra. 
Dojrzałość europejskiego procesu politycznego nie jest per se wiadomością dobrą lub złą. Można nawet domniemywać, że odnowienie podziałów partyjnych i politycznych według nowych kryteriów podziału może być dla całej polityki doświadczeniem odświeżającym. Trzeba pamiętać, że dzisiejsza scena polityczna (konserwatyści, chadecy, liberałowie, socjaliści) wynika w zasadzie z podziałów XIX-wiecznych z niewielkim dodatkiem zmian, jakie przyniósł wiek XX (ruchy ekologiczne i feministyczne). Dopiero uparte nieprzyjmowanie do wiadomości redefinicji stawki i pola gry oznaczać będzie potwierdzenie popularnie wyrażanego sądu, że dzisiejsi przywódcy europejscy nie są w stanie dorównać swoim wielkim poprzednikom.

Używanie do opisu rzeczywistości XXI w. takich pojęć jak federacja i konfederacja to zagadnienie ważne per se, lecz podkreślone przez specyfikę polskich badań nad Unią Europejską, które zostały zapoczątkowane na gruncie nauk prawnych ${ }^{32}$. Ta prawnicza dominacja miała i ma do dziś swoje konsekwencje w „opowiadaniu” o Europie, gdyż w tym świetle federacja to po prostu forma organizacyjna państwa, a nie reguła podziału kompetencji wynikających z suwerenności. Klasycznym przykładem takiego rozumowania jest praca znakomitego znawcy UE, prof. Jana Barcza.

Pisząc o próbach kwalifikacji UE jako federacji (państwa federalnego), Barcz podkreśla, że ani przedlizbońska, ani polizbońska Unia nie spełnia żadnego z kryteriów - nawet ostrożnie formułowanych - uzasadniających takie traktowanie, tj. nie ma konstytucji, władzy zwierzchniej oraz narodu ${ }^{33}$. Jest to konstatacja ze wszech miar słuszna, jednakże pod warunkiem przyjęcia założenia, że federacja (europejska) musi oznaczać współczesne państwo federalne. W tym ujęciu „słowo na F"34 jest w zasadzie drugorzędne, gdyż Unia nie ma możliwości realizacji warunków związanych z byciem jakimkolwiek państwem. Takie rozumowanie, prawidłowe pod względem logicznym

32 Zbliża to polską naukę do nauki niemieckiej, w której także takie zjawisko miało miejsce. $\mathrm{Z}$ kolei we Francji podstawowe prace powstały na gruncie nauk historycznych, a dokładniej historii współczesnej, która w Polsce nie jest dyscypliną uznaną na gruncie zasad organizacji nauki.

33 J. Barcz, Unia Europejska na rozstajach. Traktat z Lizbony. Dynamika i główne kierunki reformy ustrojowej, Instytut Wydawniczy EuroPrawo, Warszawa 2010, s. 50-52.

34 M. Burgess, In Search of the Federal Spirit: New Theoretical and Empirical Perspectives in Comparative Federalism, Oxford University Press, Oxford 2012; Stowo na " F" - miejsce federalizmu w debacie o przyszłości Unii Europejskiej, w: W. Gizicki (red.), Polityczne dylematy Europy, Wydawnictwo Adam Marszałek, Toruń 2009, s. 11-28; T.G. Ash, Let's not Fear the F-word or the C-word: We Should Move to a Federal Britain in a Confederal Europe, „The Guardian”, 21 IX 2014, www.theguardian.com/commentisfree/2014/sep/21/ not-fear-f-word-federal-britain-confederal-europe (dostęp: 20.05.2018). 
i odpowiadające literze traktatów, które uczyniły z Unii organizację międzynarodową, faktycznie zatem nie odnosi się do problemu, czy przyszłością UE jest federacja i czy jest sens cokolwiek oceniać pod kątem spełnienia tego postulatu. Dalej Barcz pisze jeszcze dosadniej. W związku z tym, że państwa wybrały model organizacji międzynarodowej, to państwo federalne nie mieści się w ,istocie prawnej” integracji, z tego samego powodu wolą państw nie jest powołanie federacji, skoro w traktacie lizbońskim zawarły decyzję o przekształceniu UE w organizację międzynarodową, znosząc jej filarową strukturę ${ }^{35}$. Idąc tym tokiem rozumowania, musielibyśmy stwierdzić, że skoro w zeszłym roku pomalowaliśmy pokój farbą akrylową na niebiesko, to nierealne i nieprawdopodobne jest, abyśmy kiedykolwiek rozważali-a tym bardziej zrealizowali - zamiar przemalowania go na żółto.

Jan Barcz stwierdza na koniec, że „odwoływanie się do tego modelu tylko niepotrzebnie «wciska» jakościowo nowe zjawiska występujące w procesie integracji europejskiej w stare ramy instytucjonalno-terminologiczne, powodując wielkie zamieszanie polityczne i prowadząc do istotnych nieporozumień". Oznacza to, iż uważa on terminy federacja i federalizacja za martwe, metaforycznie „wykute w skale” przez uczonych prawników, niepodlegające już ewolucji, jak działo się to od XVII do początku XX w. Faktem jest, że prawo międzynarodowe nadaje pojęciu federacja nadzwyczaj sztywne znaczenie, niezbyt pomocne przy analizie współczesnych procesów integracyjnych w Europie. Gdy przyjmiemy taką perspektywę, wówczas rzeczywiście narracja o Europie federalnej może być tylko wyrazem pobożnych życzeń, wiecznie odsuwającym się mirażem lub świadectwem umysłowego zapętlenia $\mathrm{w}$ archaicznych terminach.

Zupełnie inne stanowisko prezentuje Marta Rojewska. Pozostając pod wpływem anglosaskiego myślenia o federalizmie, podkreśla ona, że rozróżnić można dwa jego rozumienia. Pierwsze dotyczy jego wymiaru instytucjonalnego, czyli de facto zasad rządzących działaniem struktury, a drugie definiuje federalizm jako proces, który jest szukaniem równowagi między centralizacją a decentralizacją. Jak twierdzi zatem badaczka: „Tym samym federalizm może być rozpatrywany statycznie jako sposób zorganizowania bytu politycznego lub też dynamicznie jako proces układania relacji wewnątrz bytu politycznego. Można założyć, że w przypadku integracji europejskiej federalizm będzie rozumiany jako cel integracji (statycznie) lub jako jej metoda (dynamicznie). O problemach związanych ze zdefiniowaniem federalizmu oraz stworzeniem

35 J. Barcz, Unia Europejska, s. 53. 
jego jednolitej „wielkiej teorii” najlepiej świadczy, że te dwa procesy, centralizacja i decentralizacja, są traktowane jako baza do dokonania kolejnego rozróżnienia. Dwa podstawowe i najbardziej ogólne rozumienia federalizmu jako integracji i jako decentralizacji - tworzą pewne dwie skrajne wartości skali. W pierwszej interpretacji federalizm oznacza integrację bez zacierania różnorodności. W drugiej - jest decentralizacją bez rezygnowania z jedności. $\mathrm{W}$ efekcie $\mathrm{w}$ idei federalnej otrzymujemy syntezę jedności i różnorodności, będącą zaprzeczeniem centralizacji i partykularyzmu. To pozornie sprzeczne rozumienie federalizmu stanowi o jego wielkiej wartości jako metody organizacji wspólnot społecznych (np. politycznych czy gospodarczych)"36.

Rozważono kontrowersje związane $\mathrm{z}$ pojęciem federacji jako możliwego finalité politique i zestawiono dwie przeciwstawne oceny jego przydatności w celu zilustrowania szerszego zjawiska, chociaż poza postulatem federalizacji trudno wskazać inny nazwany i świadomie promowany projekt ostatecznego kształtu już zintegrowanej Europy. Wracając do pierwszego pytania, na ile opowieść powinna odnosić się do wspomnianego finalité - czy wspomniane zawężanie kanału-zakresu możliwości nie spowoduje trudności z uzyskaniem poparcia dla jedności kontynentu, która będzie musiała być coraz bardziej konkretna?

Opowieść o wspólnej Europie nie powinna być opisem rzeczywistości „za 10 lat, jak dobrze pójdzie”, czyli nie może być projekcją zamiarów polityków, nawet tych czynionych w najlepszej wierze. Wtedy do jej badania trzeba by użyć analizy polityki zagranicznej państwa i rozważać przyszłe stany jako cele $\mathrm{i}$ interesy, a chodzi przecież o inną płaszczyznę mówienia o przyszłości. Tym samym np. Agenda Przywódców zaproponowana jesienią 2017 r. przez Donalda Truska nie może być traktowana jako nowe otwarcie. Racjonalizm i możliwości wprowadzenia w życia to za mało, aby można myśleć o narracji będącej w stanie pełnić swoje funkcje - mobilizacyjną, legitymizacyjną i profetyczną. Pierwszy krok to identyfikacja autorów konkurencyjnych, antyeuropejskich narracji. Dokonał tego Emmanuel Macron w programowym przemówieniu wygłoszonym 26 września 2017 r. na Sorbonie. Wypowiedział wtedy następujące słowa: „Zatem [Unia Europejska - P.B.] dzisiaj widzi się słabszą, wystawioną na wichry globalizacji i, co gorsza, na oddziaływanie idei, które prezentują siebie jako właściwsze rozwiązania. Mają one nazwy: nacjonalizm, protekcjonizm, izolacjonistyczny suwerenizm oraz podejście

36 M. Rojewska, Problem aktualności federalistycznych koncepcji integracji europejskiej u progu XXI wieku, praca doktorska obroniona na Wydziale Nauk Politycznych i Studiów Międzynarodowych Uniwersytetu Warszawskiego, Warszawa 2017, niepublikowana, s. 66. 
stawiające na tożsamośćc ${ }^{37}$. Wiele z nich już zapaliło wcześniej ognie, w których Europa mogła spłonąć, a dziś są tu z powrotem w nowych przebraniach. Mówią, że są legitymizowane, ponieważ cynicznie wykorzystują lęki społeczeństw. Ignorowaliśmy ich siłę zbyt długo"38. Tym samym należy przenieść się na pole rywalizacji, zakreślone już przez autorów tych wsobnych narracji. Niestety zwolenników jedności Europy, a także wielu badaczy - również w Polsce mamy powody, aby uderzać się w piersi - można porównać do gentlemanów, którzy dyskutują o najskuteczniejszych technikach uderzeń bili kijem w snookerze (jaki mostek, ile palców i jaki kąt odejścia!), gdy reszta świata skupiona jest na stadionie rugby i widzi, że jakoś drużyna proeuropejska nie wychodzi na murawę. Nie należy zatem dziwić się padającym epitetom o tchórzostwie, elityzmie i anachroniczności. Uznanie, że skuteczne narracje, a nawet polityczne baśnie wyznaczają pole rywalizacji samego centrum polityki europejskiej to niezbędny pierwszy krok. Język wartości i historii, dobra i zła, rządzenia, a nie zarządzania, to konieczne narzędzie. Macron proponuje także treść komunikatu, z którą oczywiście można dyskutować: „Musimy ich przekonać, że poprzednie 70 lat [pokoju - P.B.] nie wydarzyło się przez przypadek, lecz były owocem nieustępliwej determinacji zakotwiczonej w czystym optymizmie. Musimy odkryć na nowo ambicję Europy, która pozwoliła nam odwrócić się plecami do wojny jako takiej. Dzisiaj mieszkańcy nie wiedzą niemal nic o zniszczonych miastach i miasteczkach, ogrodzeniach z drutu kolczastego, które dzielą, co miało miejsce kiedyś w sercu Europy" 39 . Należy uznać, że politycy nie są wybierani do rozwiązywania problemów związanych z zaopatrzeniem $\mathrm{w}$ ciepłą wodę, ale do podejmowania zasadniczych decyzji o charakterze moralnym i mających odniesienie do sensu istnienia i funkcjonowania wspólnoty. Stanowi to wielki powrót polityki per se, a w centrum tego powrotu znajdują się zakres i podstawa przynależności do wspólnoty politycznej, a ta jest zawsze wyobrażona i zakomunikowana przez opowieść. Tak jak produktami opowieści były XIX-wieczne narody, nieistniejące przecież wcześniej, ale nazwane i promowane jako samotłumaczące się byty, tak obecnie mamy do czynienia ze sporem o wyznaczenie kluczowej wspólnoty i warunków uczestniczenia w niej. To, że ma być ona najpierw

37 W języku angielskim ,identitiarizm”, w języku francuskim ,identitiarisme”.

38 Wersja angielska przemówienia E. Macrona dostępna na:http://international.blogs.ouest-france.fr/archive/2017/09/29/macron-sorbonne-verbatim-europe-18583.html, wersja francuska: http://www.elysee.fr/declarations/article/initiative-pour-l-europe-discours-d-emmanuel-macron-pour-une-europe-souveraine-unie-democratique (dostęp: 20.05.2018).

Ibidem. 
wymyślona, a dopiero potem realizowana nie powinno budzić niepokoju ani niesmaku - tak bywało w przeszłości, chociaż pozytywistyczny duch nauki, kolejny produkt XIX-wiecznej narracji, próbował przekonać badaczy, że było inaczej. Podstawą sformułowania skutecznej opowieści o Europie musi być jej ambicja tworzenia czegoś nowego, a nie odkrywania reguł rządzących życiem społecznym, które obiektywnie istnieją.

Takie postawienie sprawy ma konsekwencje nie tylko dla polityków, którzy korzystając z usług specjalistów od marketingu politycznego, zaadaptowali reguły tworzenia spójnej narracji na płaszczyźnie taktycznej (słynne przekazy dnia), ale wciąż mają problemy z przyjęciem podobnego założenia na płaszczyźnie strategii. Ma także ogromne konsekwencje dla badaczy Unii Europejskiej, czy też szerzej całej Europy. Narracje nie są obiektywne, tak jak usensownienia dziejów nie są neutralne ani równie dopuszczalne (wystarczy wspomnieć propozycję nadania tego sensu przez postawienie w centrum rasy aryjskiej). Badacz rzeczywistości społecznej staje przed wyborem próby zachowania obiektywności rozumianej jako nieopowiadanie się po żadnej ze stron, odmową wartościowania analizowanych narracji inaczej niż pod względem ich spójności i wewnętrznej logiki, a jasnym opowiedzeniem się po jednej ze stron. Metaforycznie musi stwierdzić, czy chce być Edmundem Burkiem, Condorcetem, Marcusem, czy też stwierdzić, że on tylko przykłada szkiełko i oko, czy może raczej reflektor, który oświetla zarówno fakt popełniania morderstwa, jak i ratowania życia. Badacze UE nie są na to gotowi, ponieważ dopiero niedawno część $\mathrm{z}$ nich przestała być apologetami „europejskości”, inni zaś przyjęli do wiadomości istnienie konstruktywizmu i reflektywizmu, ale jako ciekawostki (ewentualnie element „lewackości”), a nie dopuszczalne i legitymizowane propozycje metodologiczne.

Mówienie o Europie zawsze było polityczne, gdyż, jak pisał Gerard Delanty, ona nie istnieje poza wyobrażeniami i następującymi w sekwencji narracjami. Uznanie tej polityczności i tym samym wzięcie odpowiedzialności za słowo bez stania się sługą programu politycznego dopiero przed środowiskiem europeistów w Polsce.

\section{Bibliografia}

A People's Europe, Report of the ad hoc Committe, Bulletin of thje European Communities, Supplement 7/85, http://aei.pitt.edu/992/1/andonnino_report_peoples_europe.pdf.

Ash T.G., Let's not Fear the F-word or the C-word: We Should Move to a Federal Britain in a Confederal Europe, „The Guardian”, 21 IX 2014, www.theguardian.com/commentisfree/2014/sep/21/not-fear-f-word-federal-britain-confederal-europe. 
Barcz J., Unia Europejska na rozstajach. Traktat z Lizbony. Dynamika i główne kierunki reformy ustrojowej, Instytut Wydawniczy EuroPrawo, Warszawa 2010.

Baun M.J., An Imperfect Union: The Maastricht Treaty and the New Politics of European Integration, Westview Press, Boulder 1996.

Borkowski P., Między poszukiwaniem prawdy o społeczeństwie a jej posiadaniem-demokracja liberalna w odwrocie, „Myśl Polityczna i Ekonomiczna” 2018 (w przygotowaniu).

Borkowski P., Międzyrzadowość w procesie integracji europejskiej, Oficyna Wydawnicza ASPRA-JR, Warszawa 2013.

Borkowski P., Unia Europejska - groźba implozji, „Rocznik Strategiczny 2011/2012” Warszawa 2012, edycja 16.

Burgess M., In Search of the Federal Spirit: New Theoretical and Empirical Perspectives in Comparative Federalism, Oxford University Press, Oxford 2012.

Czachór Z., Kryzys i zaburzona dynamika Unii Europejskiej, Dom Wydawniczy Elipsa, Warszawa 2013,

Deklaracja Schumana - 9 maja 1950 r., https://europa.eu/european-union/about-eu/symbols/ europe-day/schuman-declaration_pl.

Dinan D., Paterson W.E., Nuggent N. (red.), The European Union in Crisis, Palgrave Macmillan, New York 2017.

Dunin-Wąsowicz M. (red.), Integracja europejska $i$ nowy lad gospodarczy. Raport, Wydawnictwo Naukowe „Scholar”, Warszawa 2012.

Giddens A., Konsekwencje nowoczesności, przeł. E. Klekot, Wydawnictwo Uniwersytetu Jagiellońskiego, Kraków 2008.

Giddens A., Nowoczesność i tożsamość, przeł. A. Szulżycka, Wydawnictwo Naukowe PWN, Warszawa 2010,

Götz M., Kryzys i przyszłość strefy euro, Difin, Warszawa 2012.

Grosse T.G., Systemowe uwarunkowania kryzysu strefy euro, E-Monografie, nr 9, Prace Naukowe Wydziału Prawa, Administracji i Ekonomii Uniwersytetu Wrocławskiego, Wrocław 2010.

Hix S., Folesdahl A., Why There is a Democratic Deficit in the EU? A Response to Majone and Moravcsik, „Journal of Common Market Studies” 2006, vol. 44, nr 3.

Hodson D., EMU and Political Union: What, If Anything, Have We Learned from The Euros First Decade?, „Journal of European Public Policy” 2009, vol. 16, nr 4.

Hoffmann S., Obstinate or Obsolate? The Fate of Nation-State and the Case of Western Europe, „Daedalus. Journal of the American Academy of Arts and Sciences” 1966, vol. 95, nr 3.

Lodge M., Regulation, the Regulatory State and European Politics, „West European Politics” 2008, vol. 31, nr 1-2.

Łastawski K., Racja stanu Rzeczpospolitej Polskiej, Wyższa Szkoła Pedagogiczna Towarzystwa Wiedzy Powszechnej, Warszawa 2000.

Majone G., From Regulatory State to a Democratic Default, „Journal of Common Market Studies" 2014, vol. 52, nr 6.

Majone G., The Rise of the Regulatory State in Europe, ,West European Politics” 1994, vol. 17, nr 3.

Michelson M., Is The European Union Too Big And Bound To Fail?, www.forbes.com/sites/marcelmichelson/2015/11/27/is-the-european-union-too-big-and-bound-to-fail/\#2f1a1e99592d.

Parzymies S., Francuskie i holenderskie „,Nie” dla traktatu konstytucyjnego spóźnionym protestem przeciwko rozszerzeniu Unii Europejskiej, „Stosunki Międzynarodowe - International Relations" 2005, nr 3/4. 
Parzymies S. (wybór i oprac.), Integracja europejska w dokumentach, Polski Instytut Spraw Międzynarodowych, Warszawa 2009.

Poboży M., Kryzys strukturalny Unii Europejskiej, w: K.A. Wojtaszczyk, J. Nadolska (red.), The European Union in Crisis, Palgrave Macmillan, New York 2017.

Przemówienie Emmanuela Macrona z 26 IX 2017 r., wersja angielska http://international. blogs.ouest-france.fr/archive/2017/09/29/macron-sorbonne-verbatim-europe-18583.html, wersja francuska: www.elysee.fr/declarations/article/initiative-pour-l-europe-discours-demmanuel-macron-pour-une-europe-souveraine-unie-democratique.

Rojewska M., Problem aktualności federalistycznych koncepcji integracji europejskiej u progu XXI wieku, praca doktorska obroniona w 2017 r. na Wydziale Nauk Politycznych i Studiów Międzynarodowych Uniwersytetu Warszawskiego, niepublikowana.

Ross G., Jenson J., Reconsidering Jacques Delors'Leadership of the European Union, ,Journal of European Integration" 2017, vol. 39, nr 2.

Schmieding H., Tough Love: The True Nature of the Eurozone Crisis, „Business Economics” 2012, vol. 47.

Schimmelfennig F., Theorising Crisis in European Integration, w: D. Dinan, W.E. Paterson, N. Nuggent (red.), The European Union in Crisis, Palgrave Macmillan, New York 2017.

Shambaugh J.C., The Euro's Three Crises, Brookings Papers on Economic Activity, Spring 2012.

Sloterdijk P., Pogarda mas: szkic o walkach kulturowych we wspótczesnym społeczeństwie, przeł. B. Baran, Czytelnik, Warszawa 2012.

Słowo na ,F”-miejsce federalizmu w debacie o przyszłości Unii Europejskiej, w: W. Gizicki (red.), Polityczne dylematy Europy, Wydawnictwo Adam Marszałek, Torun 2009.

Toszek B., Proces integracji Wielkiej Brytanii ze Wspólnotami Europejskimi $w$ latach 1961-1975, Wydawnictwo Adam Marszałek, Torun 2009.

Vimont P., The European Project in Crisis: Myths and Realities, http://carnegieeurope. eu/2017/11/17/european-project-in-crisis-myths-and-realities-pub-74770.

Voegelin E., Od Oświecenia do rewolucji, przeł. Ł. Pawłowski, Wydawnictwa Uniwersytetu Warszawskiego, Warszawa 2011.

Weber D., Can the EU Survive?, w: D. Dinan, W.E. Paterson, N. Nuggent (red.), The European Union in Crisis, Palgrave Macmillan, New York 2017.

Wojtaszczyk K.A., Nadolska J. (red.), Kryzysy w procesie integracji europejskiej i sposoby ich przezwyciężania, Oficyna Wydawnicza ASPRA-JR, Warszawa 2015.

Wypowiedź ministra spraw zagranicznych Witolda Waszczykowskiego dla mediów niemieckich, oryginalny tekst wywiadu dla „Bild”, www.bild.de/politik/ausland/polen/hat-die-regierung-einen-vogel-44003034.bild.html. 